\title{
Developmental Anatomy of Adventitious Shoot Formation on Snapdragon (Antirrhinum majus L.) Hypocotyls In Vitro
}

\author{
James S. Busse' ${ }^{1}$, M. Figueroa-Cabanas ${ }^{2}$, and D.P. Stimart ${ }^{3}$ \\ Department of Horticulture, University of Wisconsin-Madison, 1575 Linden Drive, Madison, \\ WI 53706
}

\begin{abstract}
ADDITIONAL INDEX WORDS. organogenesis, snapdragron, tissue culture
Abstract. Developmental anatomy of adventitious shoot formation in vitro from snapdragon (Antirrhinum majus L.) hypocotyls was investigated using two inbred lines, the most $(\mathrm{R})$ and least $(\mathrm{NR})$ regenerative lines selected from screening (Schroeder and Stimart, 1999). Time course analysis indicated cell division in the most regenerative line occurred first in one or a small number of epidermal cells with periclinal and anticlinal divisions within 2 days of placing hypocotyls on induction medium. Subsequently, cortical then vascular cells were recruited beneath the dividing epidermal cells. Once shoots formed, their vascular system was continuous with the original hypocotyl explant. The least regenerative line had no cell division directed towards organogenesis through 6 days. Shoot formation on snapdragon hypocotyls was adventitious in origin, by direct organogenesis and genotype dependent.
\end{abstract}

Snapdragon is important commercially as a cut flower, annual bedding plant, and potted plant. It is used widely as a model for genetic studies of floral development (Coen et al., 1990), floral pigmentation (Luo et al., 1991; Martin et al., 1987a), transposable elements (Coen and Carpenter, 1986; Luo etal., 1991; Martin et al., 1987b), and identification of mutations and gene mapping (Harte, 1974). Transformation of snapdragon would assist advancement of these studies and provide opportunities for commercial crop improvement; however, this is dependent upon knowledge of adventitious shoot regeneration.

It is common knowledge that regeneration is influenced by genotype in some species. Segregation for regeneration studies indicate regeneration is under genetic control in melon (Cucumis melo L.) (Molina and Nuez, 1996), tomato [Lycopersiconesculentum Mill. and L. peruvianum (L.) Mill.] (Koornneef et al., 1987), alfalfa (Medicago sativa L.) (Reisch and Bingham, 1980), and corn (Zea mays L.) (Duncan et al., 1985). The aforementioned reports suggest two dominant major genes control regeneration.

Genotype-dependent regeneration has been reported in snapdragon (Atkinson etal., 1989,Pfister and Widholm, 1984; Sangwan and Sanwan, 1990; Schroeder and Stimart, 1999). Schroeder and Stimart (1999) reported an inbred snapdragon population segregated for regeneration and this trait appeared to be dominant. The early cellular and tissue events of organogenesis are not known for these inbred lines, and very little is known about regeneration in snapdragon in general.

Most reports of in vitro organogenesis with snapdragon indicate it occurs indirectly after callus formation. Poirier-Hamon et al. (1974) reported extensive callusing of internodal explants and "sub-epidermal origin of embryoids" within 2 weeks on induction medium. Sangwan and Harada (1975) reported callus growth on the basal end of stem explants as well as on margins

Received for publication 10 Aug. 2004. Accepted for publication 8 Oct. 2004 Use of trade names does not imply endorsement of the products named or criticism of similar ones not named.

${ }^{1}$ Assistant Scientist.

${ }^{2}$ Research Assistant

${ }^{3}$ Professor and Chair. To whom reprint requests should be addressed. Email address: dstimart@wisc.edu of leaf-disk explants preceding the development of meristematic regions which produced embryos and ultimately plantlets. Pfister and Widholm (1984) found plants could be regenerated from calli initiated from seedling root and shoot explants. Atkinson et al. (1989) used hypocotyl explants and found "an embryonic mode of regeneration" following the production of callus in some snapdragon cultivars. Many of these researchers conducted experiments for a minimum of 2 weeks and the early events of organogenesis may have been missed.

An anatomical study was undertaken to investigate adventitious shoot regeneration on snapdragon hypocotyls in vitro. Specifically, we wanted to document the early events of regeneration in a regenerative line as well as check for any evidence of the early events of regeneration in a nonregenerative line.

\section{Materials and Methods}

Plant material. Two inbred lines of snapdragon derived by self pollination and single seed descent to the $\mathrm{F}_{7}$ were selected for anatomical analysis. These two lines were selected from a pool of 12 inbred lines and cultivars evaluated for adventitious shoot regeneration (Schroeder and Stimart, 1999). Inbred line 1 was the most regenerative (R), and Inbred line 3 was the least regenerative (NR) (Schroeder and Stimart, 1999).

Seed Germination Medium. Seeds were sterilized by stirring them for $12 \mathrm{~min}$ in $1.57 \% \mathrm{w} / \mathrm{v} \mathrm{NaOCl}$ and $0.1 \% \mathrm{v} / \mathrm{v}$ Tween 20 and rinsed three times with sterile $\mathrm{dH}_{2} \mathrm{O}$. Seeds were sown using sterile technique in GA-7 containers (Magenta Co., Chicago), which contained half-strength MS medium (Murashige and Skoog, 1962) amended with $0.28 \mathrm{~mm}$ myo-inositol, $0.6 \mu \mathrm{m}$ thiamine $\mathrm{HCl}$, and $14.7 \mathrm{~mm}$ sucrose. Medium $\mathrm{pH}$ was adjusted to 5.7 before adding Difco Bacto agar (Difco Laboratory, Detroit) at $7 \mathrm{~g} \cdot \mathrm{L}^{-1}$ and autoclaving for $30 \mathrm{~min}$ at $120^{\circ} \mathrm{C}$ and $104 \mathrm{kPa}$. The containers were placed in a growth chamber at $25^{\circ} \mathrm{C}$ under a $16-\mathrm{h}$ photoperiod at $30 \mu \mathrm{mol} \cdot \mathrm{m}^{-2} \cdot \mathrm{s}^{-1}$ lighting provided by cool-white fluorescent lights.

InDUCTION MEDIUM. Twelve-day-old seedlings were decapitated and a 1-cm section of hypocotyl excised as the explant. Explants were placed horizontally on the surface of MS induction medium 
supplemented with $0.56 \mathrm{~mm}$ myo-inositol, $1.2 \mu \mathrm{M}$ thiamine $\mathrm{HCl}$, $88 \mathrm{~mm}$ sucrose, and $2.22 \mu \mathrm{M}$ BA (Schroeder and Stimart, 1999). Explants were prepared and grown to harvest at one time. Thus, excised hypocotyls were on induction medium for 6, 4, and $2 \mathrm{~d}$. Control material was prepared from excised hypocotyls not placed on induction medium prior to processing for microscopy.

Scanning ELECTron Microscopy. Material was fixed for $4 \mathrm{~h}$ in $5 \% \mathrm{w} / \mathrm{v}$ glutaraldehyde in $0.05 \mathrm{~m}$ sodium cacodylate buffer at $\mathrm{pH} 7.0$, with a change of fresh fixative after $2 \mathrm{~h}$. Tissue was rinsed with buffer, dehydrated with ethanol and critical point dried. An E5000M (Bio-Rad, Polaron Division, Hemel Hempstead, England) sputter coater applied $350 \AA$ of gold to the samples. Material was viewed with a Hitachi S-570 (Hitachi Corp., Rolling Meadows, Ill.) scanning electron microscope at $10 \mathrm{kV}$ and photographed with Polaroid 55 Positive/Negative $4 \times 5$ Instant Sheet Film (Polaroid Corp., Bedford, Mass.). Four hypocotyls were examined from each genotype and each induction medium time for a total of 32 hypocotyls.

LIGHT MICROSCOPY. Fixation and buffer washes were performed as described above. Tissue was dehydrated with acetone, and embedded in Spurr's resin (Spurr, 1969). Two-micrometer-thick sections were cut with a Sorvall Porter-Blum MT-2 (Ivan Sorvall, Norwalk, Conn.) ultramicrotome and attached to glass slides with heat. Sections were stained with $0.05 \% \mathrm{w} / \mathrm{v}$ toluidine blue-O, viewed with a Carl Zeiss Ultraphot II (Carl Zeiss, Thornwood, N.Y.), and photographed using Kodak TMAX 100 (Eastman Kodak Co., Rochester, N.Y.).

We chose to investigate the process of shoot formation by sectioning the original explant completely in transverse fashion. Material sectioned included one complete hypocotyl from the NR line on induction medium $6 \mathrm{~d}$ and one from the $\mathrm{R}$ line on induction medium 0 and $2 \mathrm{~d}$, and two $\mathrm{R}$ lines on induction medium 4 and $6 \mathrm{~d}$.

Chearings. Excised hypocotyls were cleared in $75 \% \mathrm{v} / \mathrm{v}$ lactic acid for $24 \mathrm{~h}$ prior to staining with pararosaniline hydrochloride (Boke, 1970). The hypocotyls were dehydrated and mounted in methyl salicylate on glass slides. Sixteen hypocotyls were examined, two each from the R and NR lines from each of the four induction times.

\section{Results}

There was no indication of regeneration in the NR line over $6 \mathrm{~d}$. Thus, data presented from this point is for regeneration of $\mathrm{R}$ line.

SCANNING ELECTRON MICROSCOPY. Shoot regeneration proceeded as a regular series of events, and the developmental morphology of regenerating shoots was studied using scanning electron microscopy. After $2 \mathrm{~d}$ on induction medium, a small protuberance was observed on the surface of the hypocotyls (Fig. 1A). The protuberance continued to enlarge (Fig. 1B) and, the first visible sign of organ development was the appearance of two decussately arranged leaf primordia after $4 \mathrm{~d}$ (Fig. 1B). Occasionally, two primordia were fused along their margins to form a funnel-shaped structure (Fig. 1C). After $6 \mathrm{~d}$ on induction medium, regeneration of an organized shoot with relatively large leaf primordia was noted (Fig. 1D). Adventitious shoot initiation did not occur in synchrony. While multiple adventitious shoots were observed on each hypocotyl, these shoots were often at different developmental stages (Fig. 1B-D). Adventitious shoots of many developmental stages were observed on hypocotyl explants after $6 \mathrm{~d}$ on induction medium. Explants underwent callus formation after $6 \mathrm{~d}$ on the induction medium. Callusing was most prevalent on the proximal portion, the root end, of the explant. Formation of adventitious shoots did not require prior callus formation.

Sectioning ORIGINAL EXPLANT HYPOCOTYL. A brief description of the hypocotyl is provided. A single epidermal cell layer of 55 to 60 cells in circumference is found on the outer surface of the hypocotyl. The cells of the cortex are typically arranged in three concentric layers with the innermost cortical layer being an endodermis. The outermost portion of the vascular tissue delimited by a single cell layer, the pericycle. Pericycle cells are markedly smaller than endodermal cells which they neighbor. Two protoxylem poles define the diarch primary xylem arrangement.

Earliest signs of adventitious shoot formation always occurred in the epidermis within $2 \mathrm{~d}$ on induction medium and preceded subsequent involvement of the cortex and vascular tissues of the original explant. An epidermal cell began the process through a series of periclinal and anticlinal cell divisions (Fig. $2 \mathrm{~A}$ and B). At this early stage, the outline of the original epidermal cell could be clearly defined (Figs. 1A and 2B). In some cases, this cell was located immediately beneath a trichome (Fig. 2B) although this was not always the case. Adventitious shoot formation occurred most often at the distal end of the explant and was observed earlier there than at the proximal end.

The first cortical cells to become involved in adventitious shoot formation were those immediately beneath the dividing epidermal cells (Fig. 2C). With the increased cell division activity in the cortex, a slight outward bulge formed on the original hypocotyl explant (Fig. 2D).

More cells, both epidermal and cortical, are recruited from the original explant to initiate new rounds of cell division as the adventitious shoot develops (Fig. 2E). It was still possible to identify the original mother cell at the early stages of cortical cell divisions (Fig. 2F). Cell division then began in the endodermis which is the innermost layer of the cortex (Fig. 2F).

Sectioning Adventitious shoots. One of the 6-d-old shoots was sectioned transversely along its entire length. Utilizing both cleared and sectioned material, mature xylem and phloem along the entire adventitious shoot axis was observed in continuity with that of the original hypocotyl explant. Sections through the leaf primordia showed an organization reminiscent of a typical unexpanded dicotyledonous leaf with clearly defined dermal and ground tissue systems (Fig. 3A). The vascular tissue was organized in collateral bundles and the xylem was differentiating in an endarch manner. At $60 \mu \mathrm{m}$ below the shoot apical meristem, the vascular tissue was arranged in discrete bundles separated by interfasicular regions, which were continuous between the pith and cortex (Fig. 3B). There was no indication of a change in the direction of the xylem tissue differentiation or a spatial reorganization of the phloem tissue at this level.

Lower in the axis of the adventitious shoot, $560 \mu \mathrm{m}$ below the shoot apex, pith was present and the interfasicular regions were continuous between the pith and the cortical area (Fig. 3C). There was no indication of a central stele of vascular tissue as observed in the hypocotyl of the original explant (Fig. $1 \mathrm{~A}, \mathrm{C}$, and E). Furthermore, the cortex of the adventitious shoots was typically four cell layers thick and there was no indication of a pericyle (Fig. 3C).

Just prior to the point of attachment of the adventitious shoot with the original explant, $660 \mu \mathrm{m}$ below the shoot apical meristem, vascular elements were found throughout the central portion (Fig. 3D). The vascular tissue was not in a root-type arrangement with exarch xylem. 


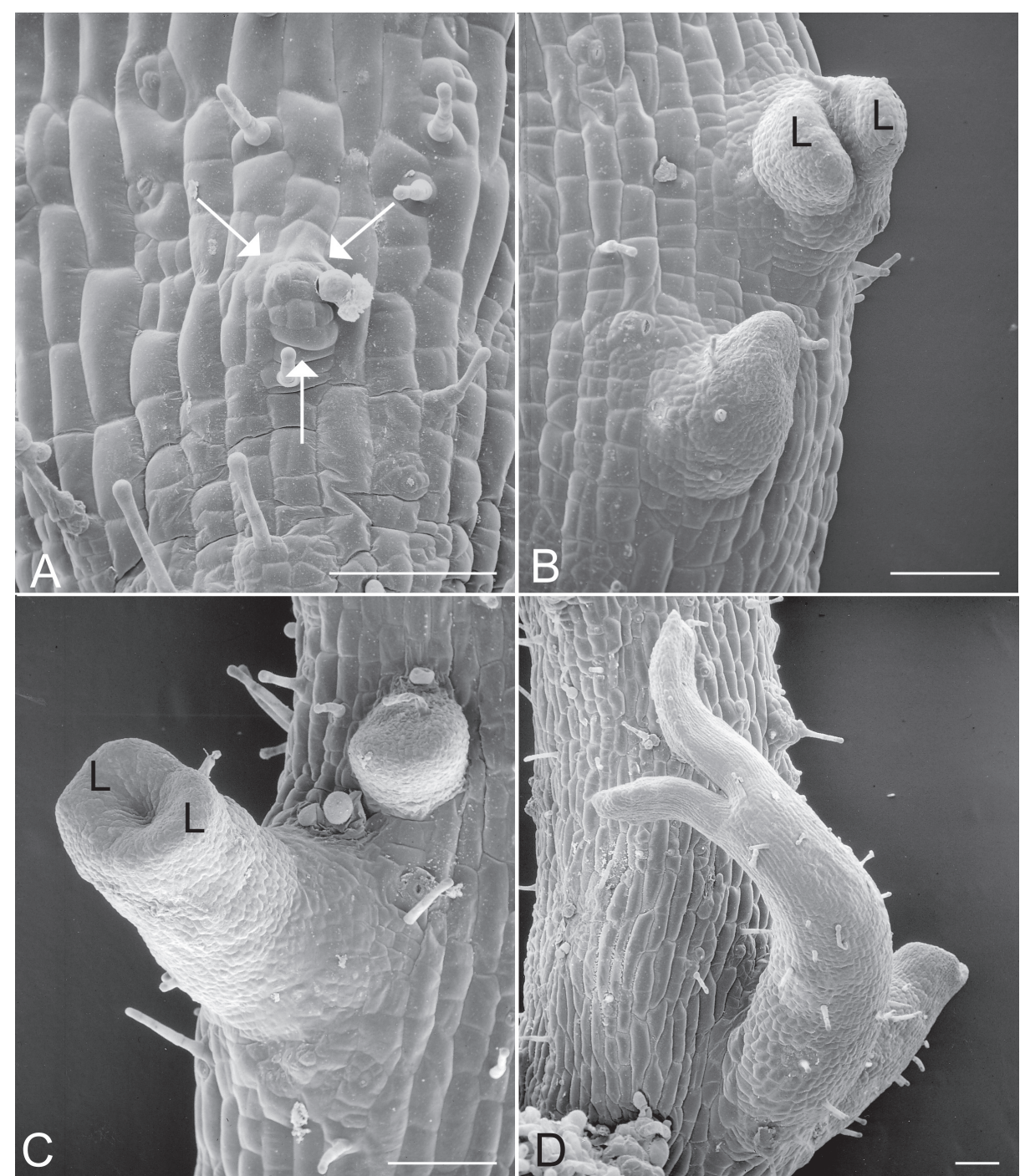

Fig. 1. Scanning electron micrographs of adventitious shoot formation on hypocotyl explants of Antirrhinum majus. A small protuberence (arrows) in the epidermis after $2 \mathrm{~d}$ on induction medium (A). Shoot formation after $4 \mathrm{~d}$ on induction medium. Leaf primordia (L) are present on some shoots $(\mathbf{B})$. Regenerated shoots at two different developmental stages after $4 \mathrm{~d}$ on induction medium. Leaf primordia (L) are fused in on shoot (C). Leaf primordia and elongated axis after $6 \mathrm{~d}$ on induction medium (D); scale bars $=150 \mu \mathrm{m}$.

\section{Discussion}

This study showed that shoot formation on snapdragon hypocotyls was adventitious in origin, direct and genotype dependent. Time course analysis of the induction phase indicated earliest signs of adventitious shoot formation occurred in the epidermis and subsequently recruited cortical and vascular tissue. Callusing did not precede organogenesis nor was organogenesis initiated sub-epidermally in our studies. Once shoots formed, their vascular systems were continuous with that of the hypocotyl. The use of juvenile tissue like the hypocotyl has been shown important in the regeneration in snapdragon (Atkinson et al., 1989; Okubo et al., 1991; Pfister and Widholm, 1984; Schroeder and Stimart, 1999). Okubo et al. (1991) reported most shoots formed from the boundary region between the hypocotyl and root. We observed adventitious shoot formation more often and earlier at the distal portion, shoot end, of the original hypocotyl; however, adventitious shoots were formed along the entire length of the hypocotyl within $6 \mathrm{~d}$ on induction medium. The basal portion (nearest the root) of the explant did form callus eventually; however, callus formation was not necessary prior to adventitious shoot formation.

Regeneration was genotype dependent, as line $\mathrm{R}$ generated shoots and line NR formed no shoots. This confirms the results of Schroeder and Stimart (1999) who found no shoots formed after 2 weeks of culture. Furthermore, there is no anatomical evidence of regeneration in the NR line during the time when the $\mathrm{R}$ line was capable of producing shoots. However, an average of 0.1 shoots formed on hypocotyls of NR after 3 weeks of culture compared to 8.4 shoots formed on the R line during the same time (Schroeder and Stimart, 1999).

Plant regeneration through adventitious shoot formation requires two separate morphogenic processes, shoot formation and root formation. This differs from somatic embryogenesis where a single regenerative event gives rise to a bipolar structure. The acquisition of bipolarity is bound to the first phases of embryogenesis, and this fundamental step differentiates embryogenesis from organogenesis (Standardi and Piccioni, 1998). Few studies describe the anatomy of direct shoot organogenesis in vitro. Bonnett and Torrey (1966) reported adventitious shoot meristems originate from the pericycle of bindweed (Convolvulus arvensis L.) roots. Meristematic activity was first noted in cambial and phloem cells of tobacco (Nicotiana tabacum L. cv. Wisconsin 38) stem explants (Sterling, 1951). In horsenettle (Solanum carolinense L.), meristematic activity for shoot organogenesis began in external phloem and inner cortical tissue of stem explants (Reynolds, 1989). Meristematic activity began in the cortex of tomato hypocotyl explants during shoot organogenesis (Newman et al., 1996). In contrast, shoot formation in our system is exogenous. First evidence of organogenesis was the appearance of anticlinal divisions in a small number of epidermal cells within $2 \mathrm{~d}$ of placement on induction medium. No rupture of the epidermis occurred, but rather it remained continuous with the original explant. Colby et al. (1991) reported similar findings using grape (Vitis vinifera L.) leaf petioles. They noted adventitious shoot meristem formation began in the epidermal or subepidermal cell layers. Similar results were obtained using cotyledon explants of douglas fir [Pseudotsuga menziesii (Mirbel) Franco.] (Cheah and Cheng, 1978) and monterey pine (Pinus radiata Linden ex. E. Fourn.) (Yeung et al., 1981), as well as internodal explants of bluewings (Torenia fournieri) (Chlyah, 1974). Apparently, exogenous adventitious shoot formation can occur on various explant sources.

Regardless of whether organogenesis occurs exogenously or endogenously, a common pattern of shoot organogenesis involves regions of high mitotic activity, which lead to the formation of meristematic centers, termed "meristemoids" (Thorpe, 1980). 


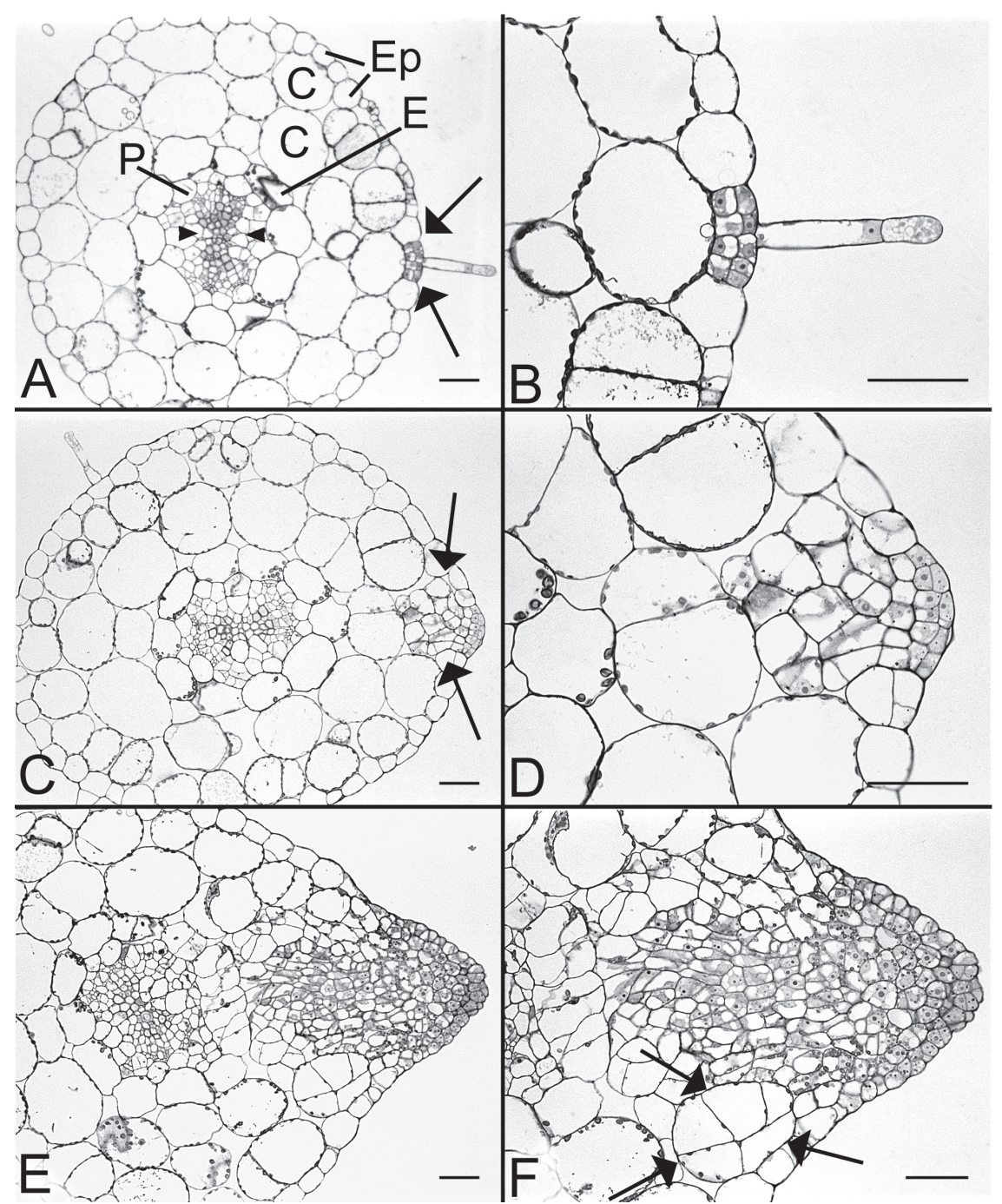

Fig. 2. Light micrographs of Antirrhinum majus. hypocotyl explants transverse sections. Dermal, ground, and vascular tissue organization is shown. Protoxylem poles are indicated with darts. Cell divisions within the epidermis are the first evidence of adventitious shoot development (arrows) after $2 \mathrm{~d}$ on induction medium (A). Higher magnification from A (B). Cells from epidermis and cortex are involved with adventitious shoot development in another location along the explant after $2 \mathrm{~d}$ on induction medium. Many cell divisions have occurred in one or a small number of cortical cells at this time (C). Higher magnification of C (D). Cells from all three tissue systems are involved in adventitious shoot formation in an explant on induction medium for $6 \mathrm{~d}$. Note how the developing adventitious shoot is a protuberence from the original hypocotyls explant (E). Higher magnification of $\mathrm{E}$. New cell divisions in this section have divided the cortical mother cell indicated by arrows $(\mathrm{F})$; $\mathrm{C}=$ cortex, $\mathrm{E}=$ endodermis, $\mathrm{Ep}=$ epidermis, $\mathrm{P}=$ pericycle, scale bars $=100 \mu \mathrm{m}$.

Esau (1977) defines a meristemoid as "a cell or group of cells constituting an active locus of meristematic activity in a tissue composed of somewhat older, differentiating cells." This definition works fine in discussions of certain aspects of plant development such as stomatal complex development during differentiation of the epidermis. However, adventitious shoot formation is really a developmental continuum from the first cell divisions of the process through the formation of an organized shoot. We find "meristemoid" difficult to define and delimit in descriptions of organogenesis and question if the term simplifies or confuses the description of adventitious shoot formation. Colby et al. (1991) also discussed the imprecision of "meristemoid." They chose to use "promeristem," although the promeristem is a small group of slowly dividing apical initials (Esau, 1965).
Adventitious shoot formation does not occur in synchrony. A wide range of shoot developmental stages were noted after $6 \mathrm{~d}$ on induction medium (Fig. 1). In some cases, well organized shoots were present (Fig. 3) while much less developed shoots were also present. This indicates that adventitious shoot induction can occur over a relatively large time span following explant placement on induction medium. This confirms our preliminary studies where we observed 12 green shoots per hypocotyl after 2 weeks and 25 shoots after 3 weeks on induction medium. Schroeder and Stimart (1999) found a 2-fold increase in shoot formation occurred from week 2 to week 3 .

While beyond the scope of this study, it would be interesting to investigate regeneration intermediates in this inbred population (Schroeder and Stimart, 1999). It is not known if the intermediates undergo regeneration in the same time frame as the $\mathrm{R}$ line investigated. Perhaps the time of regeneration initiation is no different, but rather the capacity for regeneration is reduced at the cellular level resulting in fewer shoots.

\section{Literature Cited}

Atkinson, N.J., B.V. Ford-Lloyd, and H.J. Newbury. 1989. Regeneration of plants from Antirrhinum majus L. callus. Plant Cell, Tissue Organ Cult. 17:59-70.

Boke, N.H. 1970. Clearing and staining plant materials with lactic acid and pararosaniline hydrochloride. Proc. Okla. Acad. Sci. 49:1-2.

Bonnet, H.T., Jr., and J.G. Torrey. 1966. Comparative anatomy of endogenous bud and lateral root formation in Convolvulus arvensis roots cultured in vitro. Amer. J. Bot. 53:496-507.

Cheah, K.T. and T.Y.Cheng. 1978. Histological analysis of adventitious bud formation in cultured douglas fir cotyledons. Amer. J. Bot. 65:845-849.

Chlyah, H. 1974. Etude histologique de la néoformation de méristèmes caulinaires et radiculaires à partir de segments d'entre-noeuds de Torrenia fournieri cultivés in vitro. Can J. Bot. 52:473-476.

Coen, E.S. and R. Carpenter. 1986. Transposable elements in Antirrhinum majus: Generators of genetic diversity. Trends Genet. 2:292-296.

Coen, E.S., J.M. Romero, S. Doyle, R. Elliot, G. Murphy, and R. Carpenter. 1990. Floricaula: A homeotic gene required for flower development in Antirrhinum majus. Cell 63:1311-1322.

Colby, S.M., A.M. Juncosa, J.A. Stamp, and C.P. Meredith. 1991. Developmental anatomy of direct shoot organogenesis from leaf petioles of Vitis vinifera (Vitaceae). Amer. J. Bot. 78:260-269.

Duncan, D.R., M.E. Williams, B.E. Zehr, and J.M. Widholm. 1985. The production of callus capable of plant regeneration from immature embryos of numerous Zea mays genotypes. Planta 165:322-332.

Esau, K. 1965. Plant anatomy. Wiley, New York.

Esau. L. 1977. Anatomy of seed plants. Wiley, New York.

Harte, C. 1974. Antirrhinum majus L., p. 315-331. In: R.C. King (ed.). Handbook of genetics. Plenum Press, New York.

Koorneef, M., C.J. Hanhart, and L. Martinelli. 1987. A genetic analysis of cell culture traits in tomato. Theor. Appl. Genet. 74:633-641.

Luo, D., E.S. Coen, S. Doyle, and R. Carpenter. 1991. Pigmentation mutants produced by transposon mutagenesis in Antirrhinum majus. Plant J. 1:59-69. 



Fig. 3. Transverse sections through an adventitious shoot arising from a hypocotyl of Antirrhinum majus cultured on induction medium for $6 \mathrm{~d}$ at $20 \mu \mathrm{m}$ above (A), $60 \mu \mathrm{m}$ below (B), $560 \mu \mathrm{m}$ below (C), and $660 \mu \mathrm{m}$ below shoot apical meristem (D). Entire adventitious shoot was $1320 \mu \mathrm{m}$ in length; $\mathrm{IF}=$ interfasicular region, $\mathrm{P}=$ phloem tissue, $\mathrm{X}=$ xylem tissue, $*$ pith, scale bars $=100 \mu \mathrm{m}$.
Martin, C., E.S. Coen, T. Robbins, J. Bartlett, J.Almeida, and R. Carpenter. 1987a. The control of floral pigmentation in Antirrhinum. Biochem. Soc. Trans. 15:14-17.

Martin, C., R. Carpenter, T. Robbins, A. Hudson, J. Almeida, J. Bartlett, S. Mackay, and E.S. Coen. 1987b. Transposable elements in Antirrhinum majus. J. Cell. Sci. 7:109-122.

Molina, R.V. and F. Nuez. 1996. The inheritance of organogenic response in melon. Plant Cell Tissue and Organ Culture. 46:251-256.

Murashige, T. and F. Skoog. 1962. Arevised medium for rapid growth and bioassays with tobacco tissue culture. Physiol. Plant. 15:473-497.

Newman, P.O., S. Krishnaraj, and P.K. Saxena. 1996. Regeneration of tomato (Lycopersicon esculentum Mill.): Somatic embryogenesis and shoot organogenesis from hypocotyl explants induced with 6-benzyladenine. J. Plant. Sci. 157:554-560.

Okubo, H., K. Wada, and S. Uemoto. 1991. In vitro mophogenetic response and distribution of endogenous plant hormone in hypocotyl segments of snapdragon (Antirrhinum majus L.). Plant Cell Rpts. 10:501-504.

Pfister, J.M. and J.M. Widholm. 1984. Plant regeneration from snapdragon tissue cultures. HortScience 19:852-854.

Poirier-Hamon, S., P.S. Rao, and H. Harrada. 1974. Culture of mesophyll protoplasts and stem segments of Antirrhinum majus (Snapdragon): Growth and organization of embryoids. J. Expt. Bot. 25:752-760.

Reisch, B. and E.T. Bingham. 1980. The genetic control of bud formation from callus cultures of diploid alfalfa. Plant Sci. Lett. 20:71-77.

Reynolds, T.L. 1989. Adventive organogenesis from somatic tissue cultures of Solanum carolinese: Origin and development of regenerated plants. Amer. J. Bot. 76:609-613.

Sangwan, R.S. and H. Harrada 1975. Chemical regulation of callus growth, organogenesis, plant regeneration, and somatic embryogenesis in Antirrhinum majus tissue and cell cultures. J. Expt. Bot. 26:868-881.

Sangwan, R.S. and J.S. Sangwan. 1990. Snapdragon, p. 744-762. In: P.V. Ammirato, D.A. Evans, W.R. Sharp, and Y.P.S. Bajaj (eds.). Handbook of plant cell culture. vol. 5. Ornamental ppecies. SpringerVerlag, New York.

Schroeder K.R. and D.P. Stimart. 1999. Adventitious shoot formation on excised hypocotyls of Antirrhinum majus L. (snapdragon) in vitro. HortScience 34:736-739.

Sterling, C. 1951. Origin of buds in tobacco stem segments cultured in vitro. Amer. J. Bot. 38:761-767.

Spurr, A.R. 1969. A low-viscosity epoxy resin embedding medium for electron microscopy. J. Ultrastructure Res. 26:31-43.

Standardi, A. and E. Piccioni. 1998. Recent perspectives on synthetic seed technology using nonembryogenic in vitro-derived explants. Intl. J. Plant Sci. 159(6):968-978.

Thorpe, T.E. 1980. Organogenesis in vitro: Structural, physiological, and biochemical aspects. Intl. Rev. Cytol. Suppl. 11A:71-111.

Yeung, E.C., J.Aitken, S. Biondi, and T.A. Thorpe. 1981. Shoot histogenesis in cotyledon explants of radiata pine. Bot. Gaz. 142:494-501. 